\title{
SCIENTIFIC CINEMATOGRAPHY IN GREAT BRITAIN
}

T HE second Research Film Progranme of the British Association, held at Sheffield on September 1, was opened by S. Bowler, vice-president of the Royal Photographic Society, by strongly supporting the idea of a central institute after the style of the German Institut für den wissenschaftlichen Film in Göttingen in order to raise the general standard of British research films. He was seconded by Dr. A. R. Michaelis, who had again organized the meeting on behalf of the Scientific and Technical Group of the Royal Photographic Society. Dr. V. G. W. Harrison was in the chair during the meeting, which was well attended by an audience numbering about 350 in the morning and more than 200 in the afternoon.

Outstanding among the work presented to the meeting were the two research films made by the strong team at the Chester Beatty Research Institute and University College, London. On behalf of the team, composed of P. C. T. Jones, K. Moreman (the cinematographer), D. M. Easty, M. Abercrombie and J. Santler, Dr. E. J. Ambrose introduced their film on "Interference Microscopy of Iiving Cells in Tissue Culture No. 2", in which epithelial cells were compared with certain carcinoma cells which develop from epithelium; interference cinemicrography in time-lapse frequency was employed throughout. 'This allowed not only a very clear appreciation of cytological phenomena but also often presented scientific material of great xsthetic beauty. He showed that, irrespective of their source of origin, epithelial cells formed very strong surface adhesions with each other, as distinct from carcinoma cells which moved quite independently, thus demonstrating a marked surface difference between these two types of cells.

Certain physico-chemical tests were carried out to substantiate this difference, and the negative electrical charge on the cell was measured in the presence and absence of various positive ions. The variations in the rate of movement of protein through the cell membrane in the presence of antiserum was also determined, and these changes were clearly seen in the film as rapid colour transformations in the cytoplasm of the compressed cells. The second research film from the Chester Beatty Research Institute was presented by R. J. Goldacre; it was entitled "New Aspects of Amcboid Movement". It was also recorded at time-lapse frequency, using partly phasecontrast and partly interference cinemicrography. Mechanical interference with the regulating mechanism of the polarity-conditioned locomotion of amobæ led to the discovery of three new kinds of movement which were shown in the research film: first, rapid cytoplasmic oscillations with a frequency of $1-2$ cycles per second and amplitude of 4-20 microns ; secondly, cell rotation with suppression of noticeable cytoplasmic streaming and of locomotion; and thirdly, the transmission of contraction from one end of the cell to the other. In addition, interference cinemicrography was employed to investigate ingestion of phagocytosed prey by food vacuoles.

Bacterial swarming was the subject of a further interesting biological research film, presented by Drs. P. N. Cardew and H. Hughes, of the Wright-
Fleming Institute and the Medical School, St. Mary's Hospital, London. It was called "The Swarming of Proteus vulgaris", and again time-lapse cinemicro. graphy was employed. The growth of a single cell into a colony was followed, both on the plate and microscopically; the movements of abnormal long forms and details of swarming were clearly demon. strated. Further sequences dealt with the mutual interference of incompatible strains due to the production of primary toxic products and due to a second toxic influence, the accumulation of peroxide. That time-lapse cinemicrography is not confined to biological research topics was shown in the research film sent to the meeting by J. Newkirk, of the General Electric Company, Schenectady ; it dealt with the growth, evaporation and phase-transformation of mercuric iodide crystals. The excellent use of colour in this film allowed an exceptionally clear understanding of the phenomena under investigation.

The interesting cinematographic technique of time-sampling was demonstrated in two films. The first, by .J. Robertson, of the Tavistock Clinic, showed the behaviour of a two-year-old girl in hospital, when deprived of maternal care. At standard times during the day for regular intervals over 40 -minute periods, the patient was filmed in order to obtain an objective record of her behaviour. Extracts from this scientific film, introduced by its author, showed clearly the marked difference in the child's behaviour when left to itself-fretting and depressed-and when playing with its mother during her visits-happy and contented. Next, Dr. P. Sainsbury, of the Westminster Hospital, presented his research film, "A. Method of Measuring Spontaneous Movements by 'Time-Sampling Motion Pictures". He employed it as a quantitative technique for counting the gestural movements of his patients before and after leucotomy and of other patients with nervous tics; these movements are of a kind which cannot be counted individually. A signal lamp was mounted out of view of the patient to flash at 5 or $2 \frac{1}{2}$ sec. intervals. Those intervals were counted as positive during which the specified movements occurred; when these movements were absent, the interval was scored as negative. Extracts from his research records were shown, demonstrating a decrease of gestural movements nine months after leucotomy. Further sequences dealt with the frequency of nervous tics of a number of patients during a variety of situations.

Colour schlieren cinematography at standard camera frequency was employed in the excellent film, "High-Speed Flow Around a Symmetrical Aerofoil", recently recorded by $\mathrm{S}$. Beadle, of the Shell Film Unit at the Aerodynamics Division of the National Physical Laboratory, and introduced by A. Chinneck. Both at sub- and at super-sonic velocities, the movements of shock waves and the separation of the boundary layers were beautifully demonstrated, particularly when the air flow was increased from sub- to super-sonic velocities. The effect of changes of the angle of incidence of the aerofoil was also filmed. Cinematography at normal camera frequency has proved in the past of great 
value to record an experiment, which is unique, or difficult to repeat. A recent example of such use was the film "The Release of Cosmic Ray Balloons", made and introduced by J. H. Davies, of the H. H. Wills Physical Laboratory, University of Bristol. Balloon launchings extending over several years in Great Britain and abroad were filmed, and by careful analysis of these records it was possible to improve the technique considerably. The initial acceleration of the rising bailoon could be reduced considerably by the use of a winch instead of employing many open-ended sandbags. Similarly, an undesirable mushrooming effect, leading to very high stresses in the envelope, could be eliminated by using a cord of undrawn nylon which stretched to several times its original length and thus allowed a gentle lifting of the heavy load.

High-speed cinematography was employed in three research films presented to the meeting. Wing Commander F. Latham, of the R.A.F. Institute of Aviation Medicine, Farnborough, began with unassisted escape from aircraft, showing the limitation of whole-body movements under sustained acceleration by comparing dummy and live-body trajectories on meeting high-speed slip streams at the commencement of free fall from aircraft exits. Camera frequencies up to $200 \mathrm{ft}$./sec. were used. The second stage, namely, of assisted escape from aircraft in the form of seat ejection, was similarly filmed and allowed a detailed physiological investigation of the tolerance of the human body to vertical impact acceleration and high-speed wind blasts. "Experiments of Sideways Launching" of ships was the next film to employ high-speed cinematography. It was extremely well recorded by C. A. Guthrie, of the Central Photographic Section of the National Physical Laboratory, often under most trying conditions. Scientific direction of this work was the responsibility of $\mathrm{D}$. J. Doust, and the film was introduced by $R$. Silverleaf, both of the Ship Division of the National Physical Laboratory. The main problems concerned the possibility of capsizing due to insufficient stability, structural damage, and hull pressure due to impact. Full-scale launchings were filmed, sometimes from several different camera positions at the same time, and similarly model experiments with $1 / 18$ scale models were recorded. From such experiments and these films, the performance of a variety of hull forms at launching can now be predicted and dangerous conditions of stability, way-end velocity and static drop can be avoided.

The only industrial research film presented at the meeting also employed high-speed cinematography, at a camera frequency of $1,000 \mathrm{ft} . / \mathrm{sec}$. It was made in colour and introduced by J. Underwood, of the Guest, Keen and Nettlefolds Group Research Laboratory. It dealt with "Flame Movement in an Open Hearth Furnace during Tapping" and was taken to investigate the causes of local overheating ; from the resulting records it was possible to direct the research into profitable channels. During tapping the furnace is tilted, and from the research films made during this process, it became clear that the flame was not homogeneous, that patches of unburnt oil remained, and that the existence of turbulent edges showed undesirable changes of the aerodynamic conditions.

A number of comments may be submitted in this report. Out of the eleven presented, only one research film would find undisputed international acclaimthat introduced by Dr. Ambrose. Apparently only one research worker, Dr. Sainsbury, has used scientific cinematography in a metrical manner and has derived quantitative data from his research film; the majority of those presented could have been submitted to frame-analysis and would have yielded a mass of scientific information, completely lost by mere projection and visual inspection of the film. In nearly all cases a professional photographer or cinematographer was employed in the production of each film; yet much could be said in detailed criticism. These comments are strong support for the creation of a central institute from which advice, comment and specialized equipment could be obtained.

However, the general picture is encouraging and in the years to come may lead to an improved position. There can be little doubt that the aims of the organizers of this meeting were fultilled by presenting a selection of the best research films available to an audience of scientists at the British Association. A third meeting is planned for September 7, 1957, at Dublin, and the hope can only be reiterated in this article that all those who have made new research films in the meantime will present their results ; the films should be submitted to either the Scientific and Technical Group of the Royal Photographic Society or to the Scientific Film Committee of the British Association.

A. R. Mrchaelis

\section{CLIMATOLOGY IN THE SERVICE OF MAN}

A $\mathrm{T}$ the Sheffield meeting of the British Association, A Section E (Geography), under the presidency of Prof. A. Austin Miller, of the University of Reading, devoted a day to a series of contributions on "Climatology in the Service of Man", which might well be regarded as a very appropriate development following the presidential address (summarized in Nature, September 1, p. 474).

Prof. G. Manley opened by directing attention to the growing economic significance to Britain of the fact that we now import about 4 per cent of our fuel as coal or its equivalent. This is about equal to the difference in the requirement of fuel for heating purposes imposed by a severe season as compared with a mild one-the season comprising the months September-May. Variations in demand show an approximately linear relationship with the accumulated deficit of mean monthly temperature below a value which he took as $57^{\circ}$ at sea-level. Official statistics of annual means back to 1866 have already been used in studies of variations in fuel demand; but for England and Wales monthly means are only available from 1901. Prof. Manley stated that his purpose was to extend our knowledge of the vicissitudes; he showed that a table of monthly means (Quart. J. Roy. Met. Soc., 1953) giving representative values for the past 250 years now provides a reasonable index of the probable fluctuations of the heating requirement for the greater part of Britain. $\mathrm{He}$ directed attention to the occurrence in late Victorian times of the combination of a severe winter with a protracted cold spring, which if repeated would set up demands in excess of any seasons so far experienced this century, in which $1916-17$ and $1950-51$ gave the highest values. The highly irregular incidence of severe seasons gives as yet little reason for supposing that a protracted cold season such as occurred in the 